\section{Формирование новых подходов исследовательской практики и сохранения архитектурно-археологических памятников Северного Причерноморья (Сравнительная кастеллология и цифровые технологии)}

https://doi.org/10.52603/arta.2021.30-1.19

Articolul este dedicat investigării problemelor actuale ale studiului modern și conservării patrimoniului arhitectural și arheologic al popoarelor est-europene de la nord de Marea Neagră, în baza castelologiei comparate și a technologiilor computerizate. În contextul analizei comparative a două monumente remarcabile - cetatea Belgorod (Cetatea Albă), din partea de vest a regiunii, și cetatea Tyagin, din partea de est, legate de istoria Moldovei și a Marelui Ducat al Lituaniei din secolele XIV-XV, sunt examinate tendințele și particularitățile generale ale structurii planimetrice și arhitecturii monumentelor.

Sunt prezentate rezultatele pozitive ale muncii echipelor științifice reprezentate de oameni de știință din diferite țări ale lumii, uniți prin proiecte speciale de studiere a monumentelor remarcabile, de utilizare a metodelor moderne de studiu a complexurilor arhitecturale, incluzând modelarea obiectelor individuale și crearea de modele computerizate ale monumentelor în general. A fost pusă problema necesității depunerii unor eforturi comune pentru conservarea și valorificarea turistică a patrimoniului cultural, dezvoltării relațiilor de bună vecinătate între țările din regiunea Mării Negre și Europei în ansamblu.

Cuvinte cheie: castelologie comparată, forme virtuale ale tehnologiilor digitale, principatul Moldovei, Marele Ducat al Lituaniei, Ucraina, patrimoniu istoric și cultural.

\title{
Summary \\ Formation of new approaches to the research practice and preservation of architectural and archaeological monuments of the North Black sea area (Comparative castellology and digital technologies)
}

The article is dedicated to the investigation of the current tasks of the modern study and preservation of the architectural and archaeological heritage of the peoples of Eastern Europe in the North Black Sea area based on comparative castellology and digital technologies. The comparative analysis of two outstanding monuments - the Belgorod fortress in the western part of the region and the Tyagin fortress in the eastern part, which historically go back to the history of the Moldavian and Grand Lithuanian principality of the XIV-XV centuries, is made and general trends and features in the planning structure and the architecture of the monuments are considered. The positive results of the work of scientific teams, representing scientists from different countries of the world united by special projects to study outstanding monuments, the use of modern methods of studying architectural complexes, including modeling individual objects and creating computer models of monuments in general, are presented. Questions were raised about the need for joint efforts for the preservation and tourist use of the cultural heritage, the development of good neighborly relations between the countries of the Black Sea region and Europe as a whole.

Keyworlds: comparative castellology, virtual forms of digital technology, Moldavian principality, Great Lithuanian principality, Ukraine, historical and cultural heritage. 


\section{Istoria științei. Studii interdisciplinare}

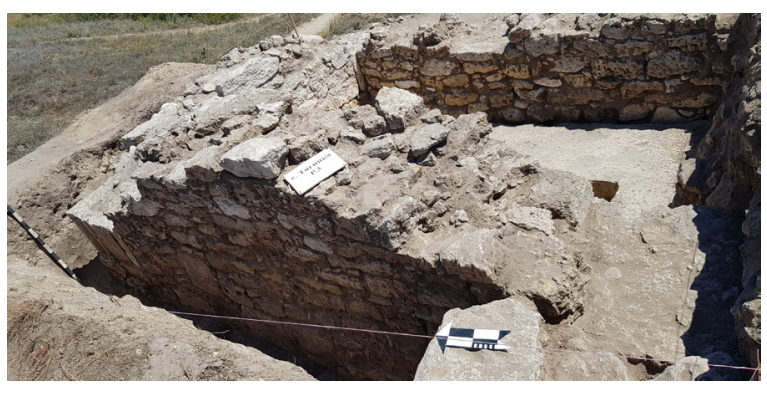

Рис.1. Остатки угловой башни, крепость Тягинь (фото Н.Бимбирайте).

Исследование памятников оборонительного зодчества неразрывно связано с важнейшими аспектами теории и практики развития науки: разработки современных подходов к изучению феномена оборонительного зодчества, сохранности архитектурно-археологического наследия в реально существующих и виртуальных формах цифровых технологий.

В теоретико-методологическом, и конкретно-историческом плане особое место принадлежит кастеллологии, выделившейся в самостоятельную область научного познания сравнительно недавно, и, получившей, на наш взгляд логичное завершение в определении: «сравнительная кастеллология» $[14$, с.31]. Ее применение позволяет расширить границы сравнительных исследований памятников различных регионов, временные рамки, определить своеобразие проявлений контактной среды и историко-культурных взаимовлияний. Накопленный к настоящему времени фонд источниковедческих исследований в области недвижимых памятников и коллекций артефактов позволяет подвести некоторые результаты и наметить дальнейшие направления современного понимания историко-культурного наследия, его сохранения и использования. Особое значение приобретают исследования переходных моментов исторического процесса. При этом источником нового этапа оборонительного зодчества является предшествующий этап, а специфика нового не предполагает полного сопротивления старому [14, c. 451]. Классические черты такого процесса хорошо прослеживаются на пространстве Cеверного Причерноморья, где с середины XIII в. до 60-70 гг. XIV в. (эпоха улуса Джучи Монгольской империи) продолжается этап существования открытых поселенческих структур, в том числе городского типа с созданием пор-

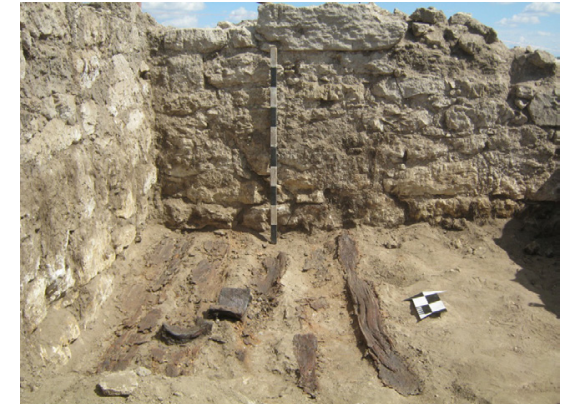

Рис.2. Остатки дощатого пола и фрагменты бомбарды (фото К.С.Гуленко).

тов, особенно в устьях крупных речных артерий, побережьям Черного и Азовского морей, которые обеспечивали функционирование ведущего экономического направления Монгольской империи - торговли. В Западной части Северного Причерноморья главная роль принадлежала городу-порту на Днестровском лимане, название которого в разные периоды существования означало Белый город (Белгород) с яркой инфраструктурой восточного образца и синкретической культурой локального варианта культуры Монгольской империи, представленной в административном делении улусом Джучи. В центральной части региона и на востоке существовали городские центры Нижнего Поднепровья, строительные остатки которых и коллекции материальной культуры составили многочисленные и разнообразные собрания эпохи. К ним в первую очередь относятся строительные остатки мечетей и мавзолеев, найденные близ с. Юрковка (Конские воды, «Семь мечетей») в Запорожской области, руины многочисленных фундаментальных построек в ур. Большие Кучугуры, на Днепропетровщине, многочисленные фрагменты лекальных кирпичей и плиток с алебастра, глиняные трубы системы водоснабжения джучидского города Тягинского городища на Херсонщине. Эти памятники имеют общие черты в архитектуре, обозначенные руинами монументальных сооружений религиозного и светского назначения: мечетей, медресе, жилых домов, мемориальных сооружений - мавзолеев и надгробных памятников. Облик материальной культуры присущ обширному ареалу Евразии, со специфическими чертами локальных проявлений культур Востока и Запада, вызванных взаимовлияниями и традициями моды. Весьма важным обстоятельством является и тот факт, что на всех этих памятниках зафиксированы строи- 


\section{Istoria științei. Studii interdisciplinare}

тельно-архитектурные детали с сельджукским декором, которые органично войдут в архитектурный декор последующего периода.

Коренные и быстрые изменения начинаются на новом этапе развития региона, когда на историческую арену выходят государства, которые создают системы защиты с сооружением замков-крепостей на основе каменного строительства. Это период сосуществования двух могущественных государств Европы: Молдавского княжества и Великого Литовского княжества. Строительная деятельность великих князей и зодчих этих государств стала новым этапом оборонного зодчества Северного Причерноморья, классическим этапом, припадающим на XIV-XV ст. Следует отметить, что результаты изучения моделей Молдавского оборонного зодчества в Северном Причерноморье, позволяют найти параллели не только в основном направлении строительства - переходе к каменному зодчеству, но и увидеть многие общие черты, позволяющие выстроить модели крепостного строительства эпохи литовского князя Витовта. Как отмечает М. Шлапак, с архитектурной точки зрения, молдавские княжеские замки-крепости находились под влиянием королевских и феодальных замков Европы, а также византийских и восточных крепостей, которые классифицируются как: замок с донжоном квадратного или прямоугольного плана; замок с донжоном треугольного плана, замок с донжоном многоугольного плана и т.д. [14, c. 237-238]. Такой замок как Белгород (Четатя Албе на карте Codex Latinus Parisinus 7239, составленной не позднее 25 сентября 1396г. [9, с.19], представляет самый древний элемент крепости-цитадель квадратной в плане формы размером 30 х 30м с четырьмя внешними башнями [6, с.39]. В процессе археологических исследований историко-архитектурных особенностей цитадели было высказано предположение о том, что первоначально она была построена с прямоугольными башнями [12, с.8-9], которые потом были перестроены, но даже в двух новых башнях были сделаны петлеобразные отверстия для мушкетного оружия. Они подобны тем, которые просматриваются в стене нижней оборонительной линии крепости. В тоже время в башне №3 зафиксирована бойница под легкую пушку, характерную для XV ст. [6, с.65, рис. 26]. По

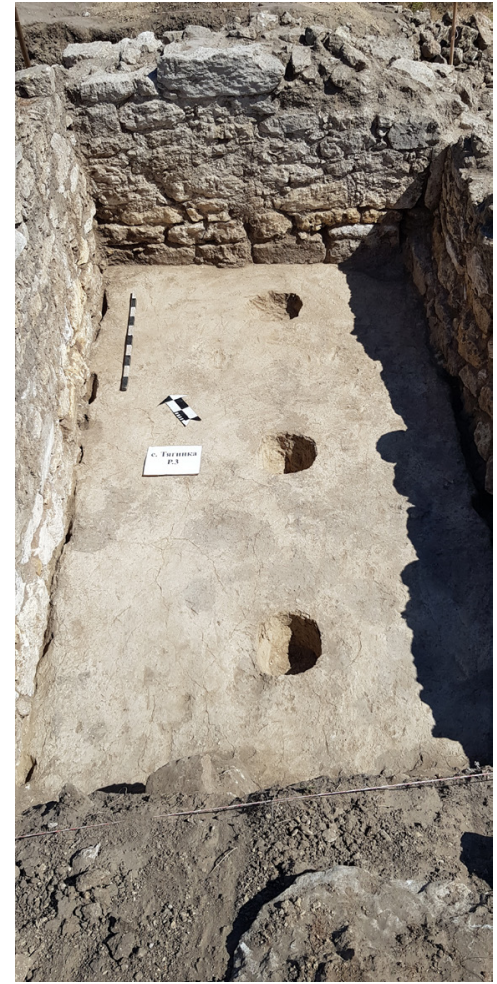

Рис.3. Крепость Тягинь, ямы от столбов, поддерживавших второй ярус башни (фото Н.Бимбирайте).

мнению М. Шлапак оборонительная архитектура крепости относится к промежуточной модели между «замок + донжон» и «замок типа кастелл». Во временном отрезке начало строительства припадает на первую четверть XV века. К наиболее ранним строениям крепости, по мнению А. Красножона, относится замок Александра Доброго, возведенный в период с 1414 г. до 1420 г. В 1420-1440 гг. Белгородский комплекс значительно расширяется, наиболее масштабный период строительства молдавского строительного периода припадает на вторую половину 1450 гг. Во второй половине 1480-х 1490гг. после перехода города к османам «замковая архитектура обновляется греческими архитекторами на османской службе» [6, с.293]. Общая площадь крепости составляет 9 гектаров.

Переход к каменной архитектуре фиксируется и на Востоке Причерноморской зоны современной Украины. Это крепость Тягинь, детище фортификационного пояса Причерноморья литовского князя Витовта, Она относится к замкам с квадратным донжоном. Его размер составлял 9 м х 9м по обмерам В. И. Гошкевича [4, с. 5-7]. Однако, по сравне- 


\section{Istoria științei. Studii interdisciplinare}

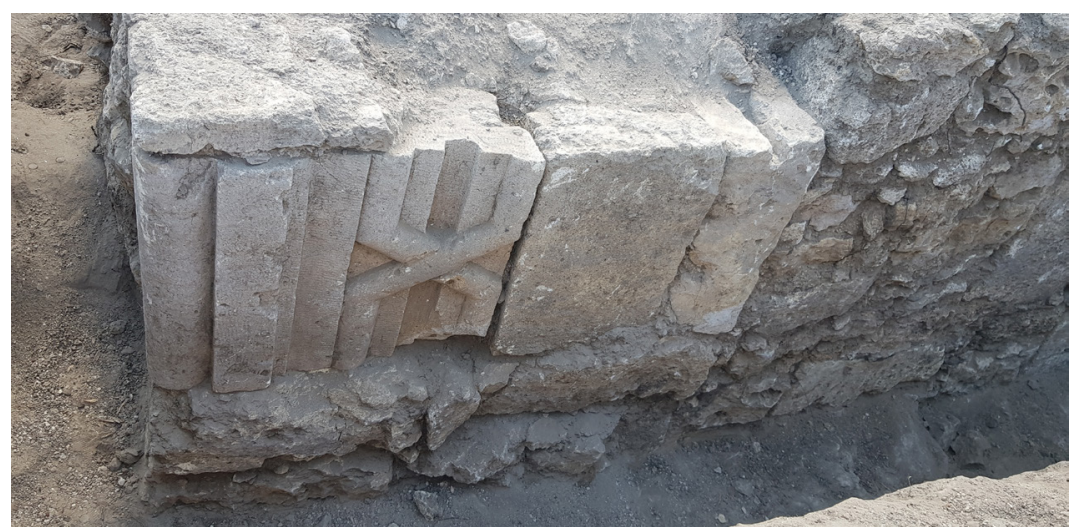

Рис.4. Крепость Тягинь. Каменная вставка с сельджукским декором (фото Н.Бимбирайте).

нию с Белгородской, это небольшая крепость, площадь которой, как было установлено в результате обмерных работ 2018 г. составляет 0,73 гектара. Несмотря на небольшие размеры, сравнительный кастеллологический анализ позволяет отметить те же тенденции крепостного строительства, ту же планировочную модель и другие, сходные историко-культурные закономерности, характерные для Белгородской крепости и многих других крепостных сооружений этого времени, в том числе, на территории Молдавии, Украины, Белоруссии, Литвы.

И именно следующей характерной чертой обеих замков является принадлежность к известной крепостной модели византийского происхождения - «константинопольской». К ней принадлежат многие крепости на Балканах, в Восточной Европе, равняясь, но, никогда не превышая самую огромную и знаменитую крепость Константинополя (150га).

Постройка Тягинской крепости имела место не ранее 1398 г.- в первой четверти XVвека, о чем свидетельствуют монетные находки, в том числе две монеты Владислава Варненчика (1434-1444 гг.), и многочисленные характерные черты материальной культуры XIV-XV вв. К тому же в 2020 году в северо-восточном углу оборонительной стены открыта каменная башня, почти прямоугольной формы площадью 20,3 кв. м., возможно представлявшая въезд на территорию крепости (рис.1). На сохранившихся восьми досках пола найдены железные фрагменты бомбарды XIV-XV ст. (рис.2), частичная реконструкция которой позволяет представить некоторые детали этого раннего типа артиллерийского оружия.

В материковом слое внутреннего помещения зафиксированы три ямы для столбов, некогда поддерживавших второй ярус башни (рис. 3). По мнению архитекторов Т.Н. Евсеевой и А.С. Луцика, судя по толщине стен и мощности столбов, некогда поддерживавших второй ярус постройки, такая башня могла быть до 9 м. высотой. Максимальная высота сохранившейся части стен составляет до $1,75 \mathrm{M}$, толщина стен 1,0 м. Стены сложены из частично обработанного известняка, на растворе, сохранили следы штукатурки и побелки, что является характерным для многих памятников крепостной архитектуры XIV-XV вв. в Литве, Белоруссии, Польше.

И, наконец, еще одна связующая деталь Белгородской и Тягинской крепости - использование образцов сельджукской каменной резьбы в интерьере той и другой крепости. Что касается Белгородской крепости, в северо-западной башне цитадели, зафиксирован фрагмент наличника, украшенного характерной сельджукской плетенкой, другой фрагмент наличника найден в гарнизонном дворе, и возможно, случайно остался среди строительных остатков в процессе перестройки какого-то объекта более раннего времени [9, c. 160-161].

В свою очередь, в Тягинской крепости еще при раскопках начала XX века В.И. Гошкевичем $[4$, c.10] были найдены фрагменты резных камней, которые орнаментально составляли части сельджукской плетенки. В 2018 г. в процессе исследования развала каменной постройки во внутреннем пространстве крепости были найдены фрагменты камней, также напоминавшие детали сельджукского декора. И, наконец, в 2020 г. при расчистке стены башни зафиксирована каменная вставка, украшенная сельджукской плетенкой (рис. 4). 


\section{Istoria științei. Studii interdisciplinare}

Оба памятника и Белгород и Тягинь Северного Причерноморского побережья представляют уникальные образцы средневекового зодчества и, на наш взгляд, нуждаются в дальнейшем изучении методами сравнительной кастеллологии, перспективным путем развития которой, в силу многочисленности деталей источников, является использование компьютерных технологий.

Кроме того, архитектурно-археологическое наследие истории и культуры Северного Причерноморья, как одного из регионов сосредоточения многочисленных памятников разных цивилизационных направлений нуждается в осуществлении целого комплекса мероприятий, которые включают все стадии исследовательского процесса, программы охраны, туристического развития также с использованием новейших методов информационного обеспечения, моделирования, создания виртуальных моделей, что позволяет создавать не только привычный статичный музейный сайт, но и дополнять интернет ресурс принципиально новым виртуальным продуктом: виртуальный тур и 3D модель экспоната [8, с.159]. Такие интернет ресурсы широко известны в практике европейского музееведения, активно представлены во многих исторических, археологических, и узко специализированных музеях, как, например, близкий к тематике наших исследований Национальный музей «Дворец Великих князей литовских» в Вильнюсе, археологический музей в Кракове, музей «Полин» (музей истории польских евреев) в Варшаве и др. Особый интерес в музее Великих литовских князей представляет виртуальный тур в средневековую

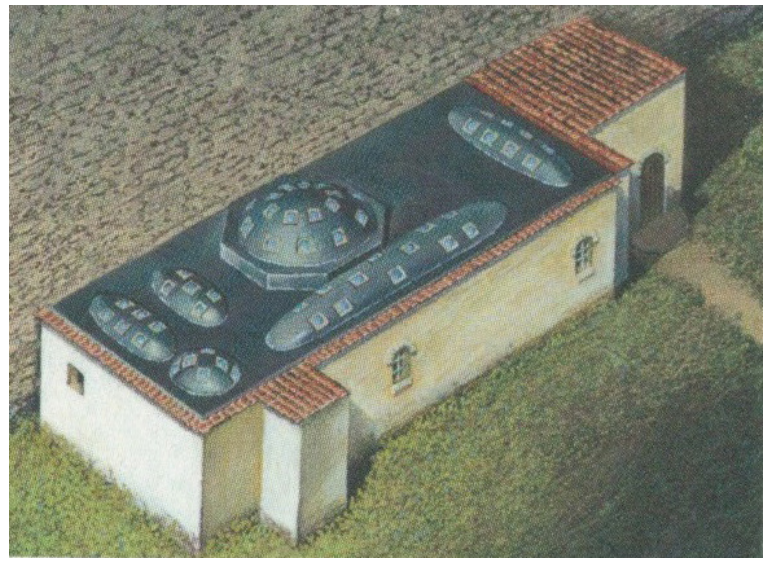

Рис.5. Белгородская крепость. Модель османской бани (по О. А. Коцюбанской ).

историю Литвы, созданный благодаря компьютерным технологиям.

В тоже время следует отметить, что недостаток исследований в области изучения историко-культурного наследия Литвы периода Великих князей литовских на территории Украины проявляется в разделе экспозиции по истории XIV-XV вв., в частности, деятельности князя Витовта по созданию оборонительной линии и организации таможенной сети на южных границах княжества. Эта часть историко-культурного наследия практически не находит своего отражения в картографических материалах в силу того, что памятники, связанные с именем Витовта еще остаются мало исследованными объектами этого времени и нуждаются в последовательном изучении на всей территории Южного региона Великого княжества Литовского.

Реализация актуальных задач создания виртуальных продуктов и моделей на терри-
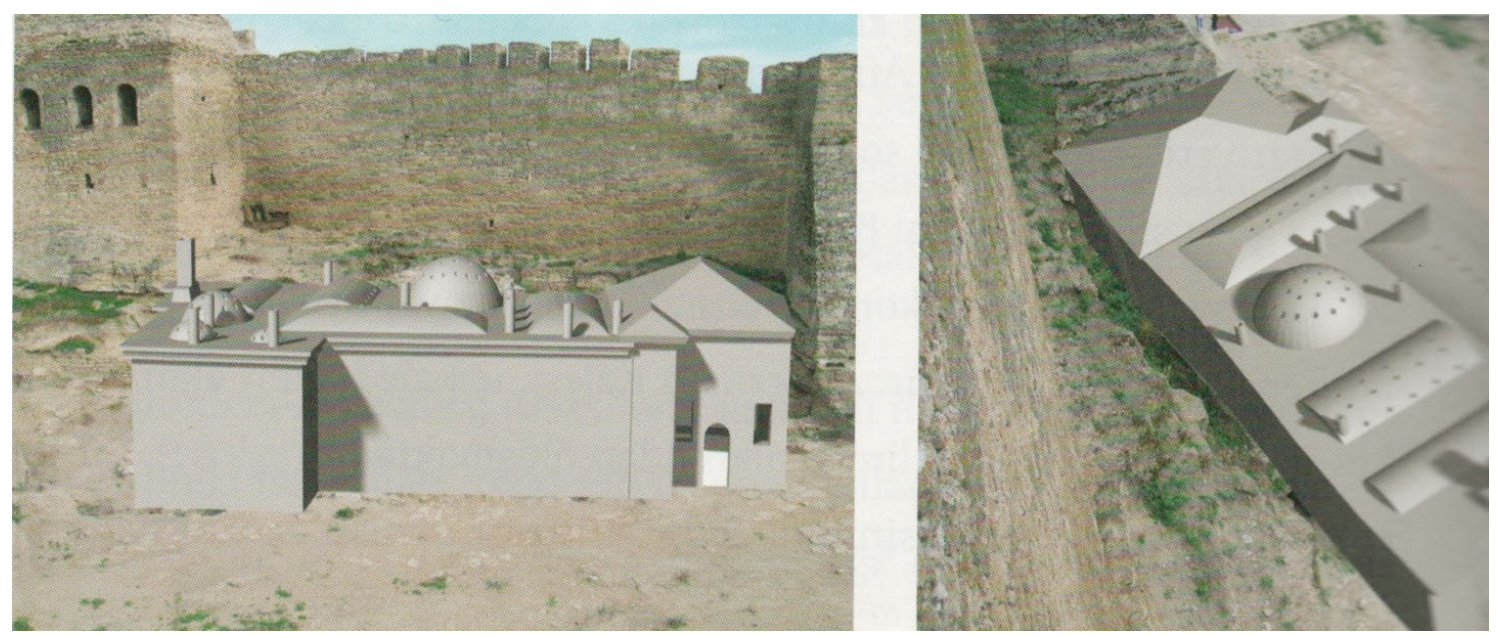

Рис.5. Белгородская крепость. Модель османской бани (по Б.Ерсою). 


\section{Istoria științei. Studii interdisciplinare}

тории нашей страны упирается в общее положение дел в области распространения и широкого введения цифровых технологий в практику изучения и сохранения культурного наследия Украины, обладающей огромными собраниями недвижимых памятников, и огромным разрывом даже в известных единицах хранения: из 12,5 миллионов единиц хранения в экспозициях представлены не более $3-5 \%$, что говорит об огромном культурном потенциале страны и несоответствии развития культурной ноосферы. Что касается развития цифровых технологий, первые шаги в Украине на общегосударственном уровне были сделаны только в средине 90-х годов XX столетия [7, с.11]. К настоящему времени наиболее важными для практики сравнительной кастеллологии в целом и конкретного хронологического периода строительства, а также существования Белгородской и Тягинской крепости являются созданные виртуальные туры «Музеи Украины под открытым небом», «Украина Инкогнита», 3D тур Острожским замком [ 7, c. 25] и некоторые другие подобные проекты, которые отражают информацию по близким культурно-хронологическим памятникам, связанным в значительной мере, как с историей и архитектурой Молдавского княжества, так и Великого княжества Литовского.

В 2013 г. в проекте «Социально-этические основы сохранения цифрового историко-культурного наследия» (Social and Ethical Foundations of Preservation of Digital HistoricalCultural Heritage) были разработаны рекомендации по сохранению и популяризации историко-культурного наследия и памятников архитектуры, в том числе по Северному Причерноморью, музеям Запорожской, Херсонской, Одесской и Николаевской области. Однако, не смотря на IT-сферы, сотрудничество между музеями и специалистами в области информационных технологий находится на начальных этапах развития. При этом, ощущается явный недостаток обоснованных разработок по составлению правил и стандартов создания цифрового ресурса, эффективности его использования, совместимости и обмена данными на локальном и международном уровне и др. аспекты создания не отдельно стоящих оцифрованных фондов, а системы. Особо важным этапом является подготовка реестра предметов культурного наследия, ко- торые подлежат оцифровке, и, конечно, создания прочной материально-технической базы внедрения новейших технологий в области культурного наследия, развитие которых в Украине еще в значительной степени отстает от европейского и мирового уровня [5, c.144].

В этой связи большие возможности представляет развитие международного сотрудничества, выполнение совместных грантов и проектов с ведущими институциями мировой науки. Исключительно позитивным примером подобных работ были исследования памятников Северного Причерноморья в рамках Южной Средневековой экспедиции Института археологии НАН Украины (начальник экспедиции и руководитель проектов С.А. Беляева) в 1997- 2006 гг. с Турецким историческим обществом и Турецким агентством по сотрудничеству и координации (ТИКА) при Совете Министров Турецкой Республики по изучению, прежде всего, историко-архитектурных памятников Очакова и Белгорода; проект Фонда Макса фон Берчема (Швейцария) в 2005-2009 гг.; проект Британского Института в Анкаре Британской Академии Наук «Археологические исследования Аккерманской крепости» в 2005-2010 гг., с участием ученых Украины, Турции, Канады, Великобритании, США; проект Культурного центра Украина-Литва «Защита исторического наследия Украины и Литвы на территории Херсонской области в рамках Программы развития сотрудничества и поддержки демократии Министерства Иностранных дел Литовской Республики в 2018 г. по исследованию памятников Великого княжества Литовского, и, прежде всего, крепости Национального значения Тягинь.

С выполнением этих проектов связаны наработки в области использования новейших технологий для комплексного изучения памятников. Так, были выполнены обмерные работы с использованием GPS Total station Trimble R-3, электронного тахеометра. Topcon GTS-239 Total station. Проведен экспериментальный цикл обмерных работ: на крепости - внедрена новая методика изучения архитектурных остатков в которой участвовали Ю.В. Болтрик, И.В. Карашевич (Станкевич), Л. Лисицкий, С. Росомаха, В. Иващук, И. Ильчишин (Украина), а также д-р. Дж. Метью (США) [12, с. 7-8]. Проведены обмеры всех строительно-архитектурных составляющих крепости: 


\section{Istoria științei. Studii interdisciplinare}

куртин, башен, построек внутри дворов. Промерена площадь каждого из дворов и общая площадь крепости. Получена компьютерная модель цитадели. После завершения обмерных работ проведена компьютерная обработка данных в специальной программе ArGIS Version 9.2. Обработка полученных данных позволила получить исходные результаты для составления уточненного плана крепости и ее отдельных составляющих, а также использования информации в сравнительной кастеллологии. Продуктивным методом изучения строительных периодов сооружения Нижней оборонительной линии, эскарпа и контрэскарпа было создание фотограмметрической модели отдельных участков (Д.В. Каравайко).

Сотрудниками Винчестерского университета (Великобритания) док. Р. Хеддлси и А. Тернер проведены пилотные геофизические обследования с тем, чтобы получить возможность локализации построек, которые не видны на поверхности, но упомянуты в Османских документах. Они использовали магнитометр Geoscan FM36 Fluxgate Gradiometer, Ground Penetrating Radar и другое оборудование, что позволило соотнести данные геофизических измерений и определить одно утраченное строение, дороги, линию внешних укреплений и некоторые другие объекты, а также различные фрагменты стен и ямы. Корреляция полученных данных с планами Аккерманской крепости конца XVIII-начала XIX ст. дает возможность соотнести некоторые объекты, зафиксированные в процессе геофизических исследований с расположением строений, зафиксированных на этих планах, а также использовать объективные данные Аккерманской крепости для сравнительного изучения других архитектурно-археологических памятников.

Одним из путей моделирования строительных объектов стала разработка методики моделирования на основе планиграфического анализа. В первую очередь такая методика была использована для учета находок фрагментов оконниц и их численности по отдельным помещениям бани. На ее основе была сделана попытка моделирования конструкции крыш всех помещений турецкой бани [3, c.277-285], а затем предложена первая модель постройки, разработанная О.О. Коцюбанской [15, с.33]. После завершения всех архитектурно-археологических исследований авторская

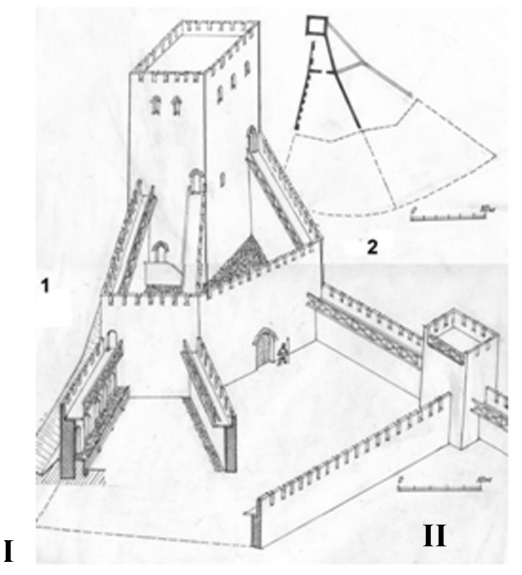

Рис.6. Вариант графической реконструкции Верхней части Тягиньской крепости (по М.М.Иевлеву).

модель бани создана руководителем исследований объекта с турецкой стороны проф. Б. Ерсоем [13, с.343]. Сравнительный анализ моделей показывает их значительное сходство, что в известной мере подтверждает рациональность и действенность методики моделирования построек с применением планиграфического анализа (рис.5).

Этот же метод был применен нами в последующем при проведении сравнительного количественного анализа, функциональной специфики и состава изделий из стекла по отдельным объектам: помещения бани и барбакана [2, с. 133-148].

Предприняты разработки проектов по созданию 3D модели Аккерманской крепости в целом, ее отдельных составляющих, в том числе цитадели, а также артефактов. В частности, были предложены разработки в области 3D моделирования фрагментов Изникской художественной керамики Турции.

Что касается Тягинского городища и крепости, в 2018 г. была проведена топографическая съемка памятников с помощью лазерного тахеометра Nicon NPL-322. Результаты обработаны с помощью программного обеспечения ArGIS 10.1.) [1, с. 28-36].

Создано ряд планов, в том числе план археологического комплекса «крепость Тягинь» на основе созданной модели рельефа, аналитических поверхностей местности, проведены обмеры на плоскости (Манигда О.В., Грабовская О.В.) Для изучения современного состояния памятника и воссоздания планировки крепости проведена низковысотная аэрофотосъемка с помощью квадрокоптера DJI Magic 


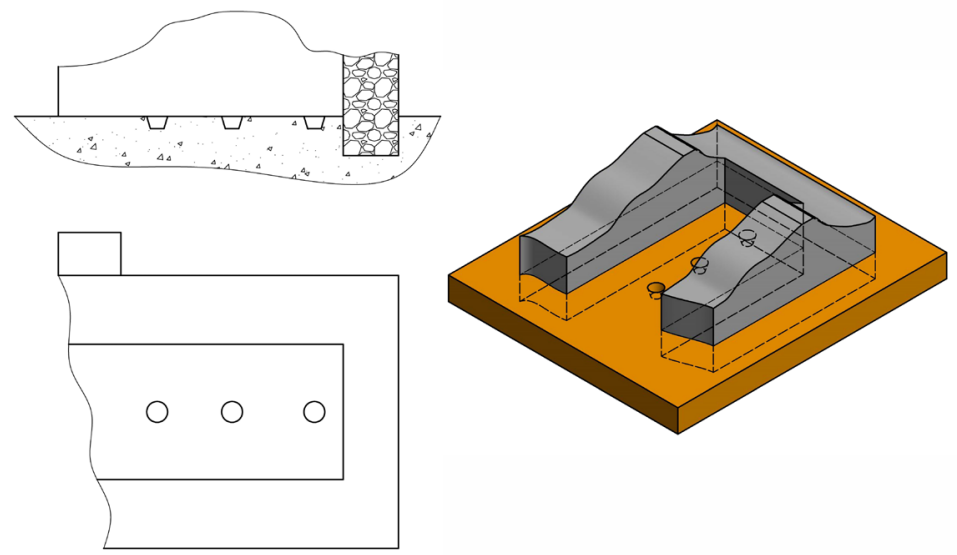

Рис.7.Нижняя часть угловой башни Тягинськой крепости (по О.А.Коцюбанской).

Air A.B. Чубенко. Создано два детальных ортофотоплана. Также для общего ГИС проекта включены интерпретированные результаты батиметрических исследований, проведенных с помощью сканера подводной поверхности SIMRAD. Результаты топографической съемки положены в основу созданной геоинформационной системы «Археологический комплекс Тягинь». М.М. Иевлевым предложена и схема графической реконструкции верхней части Тягинской крепости (рис.6). О. А. Коцюбанской предложен вариант воссоздания нижней части угловой башни (рис. 7). Кроме того, в связи с необходимостью развития туристического аспекта существования и функционирования памятника в процессе исследования крепости разработана и осуществляется методика изучения крепости в соответствии с плановой структурой, полученной благодаря низковысотной съемке, с последующей консервацией раскопов и макетированием открытых объектов (В. А. Грицаенко, М. М. Иевлев) на поверхности (рис. 8). Также подготовлена программа по созданию 3D модели крепости.

Предметом особого интереса современного этапа исследования культурного наследия Северного Причерноморья, как и Украины в целом, является необходимость развития сотрудничества с соседними государствами, такими как Турция, Румыния, Молдавия, Польша в области новых направлений, цифрового сохранения и онлайновой презентации фондов музеев и заповедников Южной Украины, которые представляют не только богатое и разнообразное культурное наследие украинского народа, но и многих народов, населявших Северное Причерноморье в прошлом и продолжающих жить на территории Украины в настоящее время. Актуальность выполнения таких задач подчеркивается нынешней ситуацией в мировом пространстве, искусственно огражденном границами в связи с пандемией.

Сравнительная кастеллология с использованием современных компьютерных технологий безусловно открывает новые перспективы исследований огромного архитектурноархеологического наследия, в том числе таких важных стратегических и геополитических регионов как Северное Причерноморье.

\section{Библиография}

1. Біляєва С. О., Гуленко К. С., Фіалко О. Є., Ієвлев М. М., Грабовська О. В., Манігда О. В., Чубенко О. В., Симоненко О. В., Дзнеладзе О. С., Сікоза Д. М. На розі двох світів. Історична спадщина України та Литви на території Херсонської області. Київ-Херсон: Гілея, 2018, 72 с. / Biliaieva S. O., Gulenko K. S., Fialko O. E., Ievlev M. M., Grabovska O. V., Manigda O.V., Chubenko O. V., Symonenko O. V., Dzneladze O. S., Sikoza D. M. Na rozi dvoh svitiv. Istorichna spadshchina Ukrainy ta Litvy na teritorii Khersonskoy oblasti. Kyiv-Kherson: Gileya, 2018, $72 \mathrm{~s}$.

2. Біляєва С.О., Фіалко О.Є. Планіграфія та типологічна характеристика скляних виробів 3 Аккерману. In: Археологія і давня історія України, (4), 2018, С. 133-148. / Biljajeva S.O., Fialko O.Je. Planighrafija ta typologhichna kharakterystyka skljanykh vyrobiv z Akkermanu. In: Arkheologhija i davnja istorija Ukrajiny, (4), 2018, s. 133-148.

3. Біляєва С.О., Фіалко О.Є., Карашевич І.В. Віконниці в системі архітектурних реконструкцій (османська лазня Аккерманської фортеці). In: Нові дослідження козацької доби в Україні. К., 2006., Вип. 15, С. 277-285. / Biljajeva S.O., Fialko O.Je., Karashevych I.V. Vikonnyci v systemi arkhitekturnykh rekonstrukcij (osmansjka laznja Akkermansjkoji forteci). In: Novi doslidzhennja kozacjkoji doby v Ukrajini. K., 2006., Vyp. 15, S. 277-285. 


\section{Istoria științei. Studii interdisciplinare}

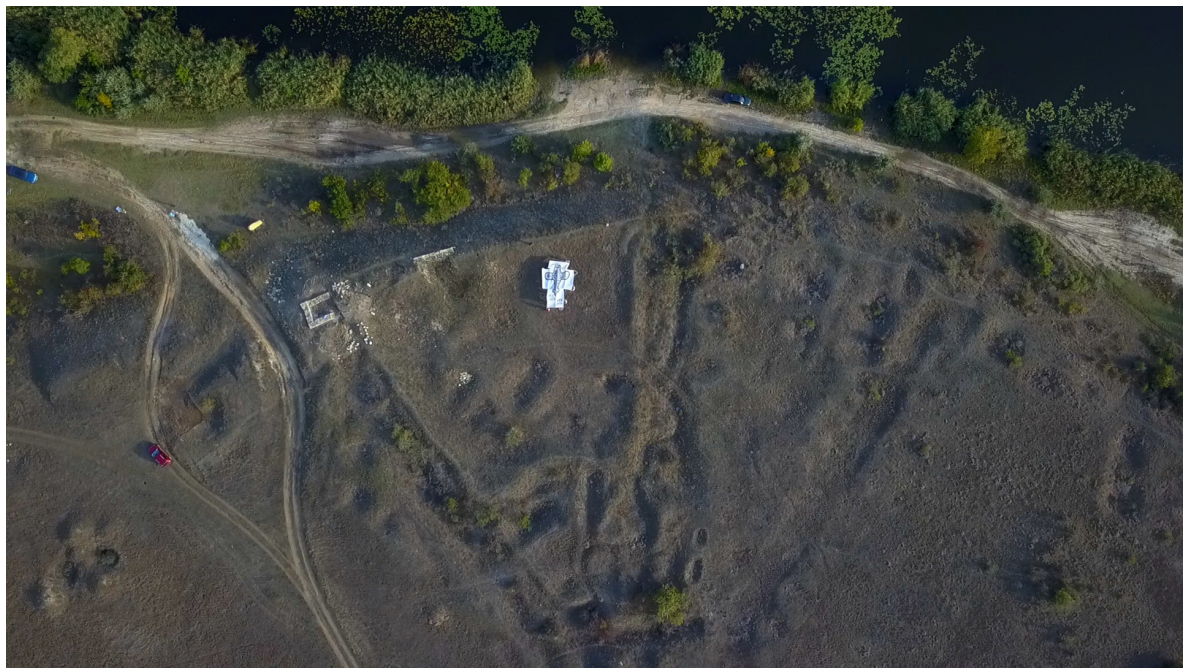

Рис.8. Макет башни Тягиньской крепости на местности (автор В. А. Грицаенко, фото Н. Бимбирайте).

4. Гошкевич В. И. Раскопки на острове против с. Тягинки. In: Летопись Херсонского музея за 1914 год. Херсон: 1916, nr. 6, 48 с. / Goshkevich V. I. Raskopki na ostrove protiv s.Tyaginki. In: Letopis Hersonskogo muzeya za 1914 god. Herson: 1916, nr, 6, 48 s.

5. Курченко Т. Стан доступу та збереження цифрової історико-культурної спадщини України на сайтах обласних краєзнавчих музеїв південного регіону України. In: Південь України: етноісторичний, мовний, культурний та релігійний виміри: V міжнар. наук. конф., 24-25 квітня 2015p. Одеса : ОМУ, 2015, С. 144-148. / Kurchenko T. Stan dostupu ta zberezhennja cyfrovoji istoryko-kuljturnoji spadshhyny Ukrajiny na sajtakh oblasnykh krajeznavchykh muzejiv pivdennogho reghionu Ukrajiny. In: Pivdenj Ukrajiny: etnoistorychnyj, movnyj, kuljturnyj ta relighijnyj vymiry: $\mathrm{V}$ mizhnar. nauk. konf., 24-25 kvitnja 2015r. Odesa : OMU, 2015, S. 144-148.

6. Красножон А.В. Фортеці та міста ПівнічноЗахідного Причорномор'я (XV-XVIIIcт.). Одеса, 2018, 310c. / Krasnozhon A.V. Forteci ta mista Pivnichno-Zakhidnogho Prychornomor'ja (XV-XVIIIst.). Odesa, 2018, $310 \mathrm{~s}$.

7. Куценко С. Ю. Особливості використання Інтернет-технологій у вітчизняній музейній практиці: моногр. Умань : ВПЦ «Візаві», 2017, 196 c. / Kutsenko S. Ju. Osoblyvosti vykorystannja Internet-tekhnologhij u vitchyznjanij muzejnij praktyci: monoghr. Umanj: VPC «Vizavi», 2017, 196 s.

8. Липак O. А. Застосування VR та AR технологій в музеях. In: Матеріали Міжнародної науково-технічної конференції «Фундаментальні та прикладні проблеми сучасних технологій» до 60-річчя 3 дня заснування Тернопільського національного технічного університету імені Івана Пулюя та 175-річчя з дня народження Івана Пулюя, 14-15 травня 2020 року. Т. : ТНТУ, 2020, С. 159-160. / Lypak O. A. Zastosuvannja VR ta AR tekhnologhij v muzejakh. In: Materialy Mizhnarodnoji naukovo-tekhnichnoji konferenciji «Fundamentaljni ta prykladni problemy suchasnykh tekhnologhij» do 60-richchja z dnja zasnuvannja Ternopiljsjkogho nacionaljnogho tekhnichnogho universytetu imeni Ivana Puljuja ta 175 -richchja $\mathrm{z}$ dnja narodzhennja Ivana Puljuja, 14-15 travnja 2020 roku. : TNTU, 2020, S. $159-160$.

9. Шлапак М. Белгород-Днестровская крепость. Исследование средневекового оборонного зодчества. Кишинев: ARC, 2001, 238 с. / Shlapak M. Belgorod-Dnestrovskaya krepost. Issledovania srednevekovogo oboronnogo zodchestva. Kishinev: ARC, 2001, $238 \mathrm{~s}$.

10. Biliaieva S.,Fialko O.,Turner A., Wazny T. Historical-archaeological investigation at Akkerman (Bilhorod-Dnistrovsky) fortress, Ukraine, 2010. Anatolian Archaeology, vol. 16 (2010), s. 7-8.

11. Ersoy B. Akkerman Kalesi, Osmanli hamami. Ege Üniversitesi arkeoloji kazilari. Ege Üniversitesi, Izmir, 2012, p.338-348.

12. Finkel C. Biliaieva S., Ostapchuk V. Historical-archaeological investigations at Akkerman (Bilhorod-Dnistrovsky) fortress, Ukraine, 2008. Anatolian archaeology. Vol. 14 (2008), s. 8-10.

13. Șlapac M. Cetăți mică enciclopedie ilustrată. Editura ARC. 2008, 56 s.

Șlapac M. Castelologia comparată. Editura ARC. 2020, 459 s. 